\title{
FORMATION OF FOLK TALES IN KODAVERE PARISH
}

\section{Mall Hiiemäe}

\begin{abstract}
The article focuses on personal narratives of narrow distribution area about locally known characters and true life events. The study is based on author's observations from a 1966 collection expedition to the peripheral rural area, where the story-telling tradition is still active. The article analyses the formation and development process of folk tale from passing on personal experiences to its formation into a folk tale type. The focus is on the genesis stage, when the audience accepts the tales authorship, the tale type is still in the inchoate stage, the genre classification vague, but traditional stylistic devices and some more widely spread folk tale motifs are already used.
\end{abstract}

Keywords: .folk tales, folklorisation process, memorate, narrator.

\section{From the author}

The use of magnetic tape recorders was introduced only in the mid-1950s, during the yearly field work expeditions of the Estonian Folklore Archives. During these years the expeditions took folklore scholars into a peripheral region in East Estonia, where, much to their amazement, they discovered brilliant story-tellers, who were greatly esteemed by the villagers. It was also surprising that the narrators were very skilled in inventing humorous tales about funny incidents in the village and the human qualities of people they knew. The stories were written down and the performances of story-tellers were recorded.

An opportunity to observe the development of the tale repertoire discussed in the article opened up ten or so years later. While collecting folklore as a student, I had already submitted to the archives tales told by hunters I knew and my own family members, which were repeatedly told while relying on real life facts (see Hiiemäe 2001). In the Soviet Estonian folklore studies, the issues of genre categorisation and typology were extremely topical; scholars were involved in categorising text corpora under genres and conducting typological work at texts. These particular tales, however, did not fit under any known genre. 
Fortunately, an interest towards the same issues was growing on the international scene; some of the issues are still topical. My study is based on the works of authors from former Socialist countries (Czechoslovakia, Hungary, German, Russian, etc.) as well as on the proceedings of the 1961 International Society of Folk Narrative Research Congress, held in Kiel and Copenhagen, available to me at the time. The observation of the narrative traditions of the Kodavere area during a month of fieldwork in summer 1966 enabled me to reach my own conclusions on the formation of the tales and the role of narrator. The article published here was completed in 1967.

\section{Introduction}

The Estonian folklore archives contain more than two thousand records of folk tales from Kodavere parish, Central-East Estonia ${ }^{1}$. Most of the tales (more than two thirds) have been collected over the past thirty years. The aims and topics of collecting of the collectors and recorders of these tales have varied over the years, thus the material does not provide an accurate proportion of the genre classification of the active repertoire ${ }^{2}$. Even the definition of folk tale boundaries has changed over the time. Personal and situational narratives, or pajatused in Estonian, have emerged only in recent years in addition to the traditional narrative genres (folk tale, legend and joke) (Laugaste 1957: 67-70; Laugaste, Normann 1959: 32-37; Tedre 1965: 64). A prerequisite of the term personal and situational narrative is the genre's strong association with the concrete: persons of local fame, specific events and settings, either forming a background to the persons and events or (less frequently) independently. This appears to be particularly characteristic of the humorous Kodavere tales, which are so unique that even a new term was derived in the Estonian language - pajatused.

So far, scholars of folklore have noted the abundance of humorous stories from the Kodavere parish. It has been mentioned, for example, that even though humorous and situational narratives have been recorded elsewhere, those in Kodavere share a particularly unique style (Lätt 1962: 3). Some of the Kodavere tales are strongly regional, being based on real life facts, but thus also limited in spread both in time and space, thus justifying the ques- 
tion to which extent can these tales be regarded as folklore (see e.g. Sirovatka 1961: 470-474; Ferenczi 1966: 49-73; Neumann 1966: 177-190).

If we separate traditional folklore genres (folk tale, legends and jokes) from the recorded Kodavere tales we will have in more than one fourth of the sc. non-traditional material that cannot be categorised under these genres. Would that mean that all the rest of the texts are personal and situational narratives? And what could be the main characteristics of these tales?

An attempt to draw a dividing line between traditional and nontraditional would be impossible and even impractical, even more so because both share considerable similarities (themes, structural devices, motifs). Nevertheless, it has to be tentatively made, in order to define personal and situational narratives, or pajatused, as an independent folk tale genre.

In local tales, people using the tales (i.e. both tellers and audience) are generally familiar with specific persons who act as characters in the stories, are familiar with concrete events and settings of the tales. Thus, it is possible to conclude that the tales contain the concrete in relation to the users (the notion of the knowledge of the concrete has been observed from the same aspect). The article observes folk tales which are primarily based on the concrete in relation to the audience (group 1, see Table). A closer look is taken at the formation or genesis and distribution of the tales, and to a certain extent also their genre classification.

The construction of tales on the concrete for the audience (on a specific person, event, setting) is unquestionably one of the most important characteristics of such tales. The first tales based on the knowledge of the concrete have been recorded in Kodavere parish as late as in the 1930s and appear rather randomly. Apparently, such tales have not been considered as folk tales proper and traditional narrative repertoire has been favoured. These tales have attracted more attention only since the fieldwork expedition of the Estonian Literary Museum in 1955. Author of this article has specifically observed the situation of the Kodavere folk tales on fieldwork expeditions to the area in August-September 1966 and January 1967. 


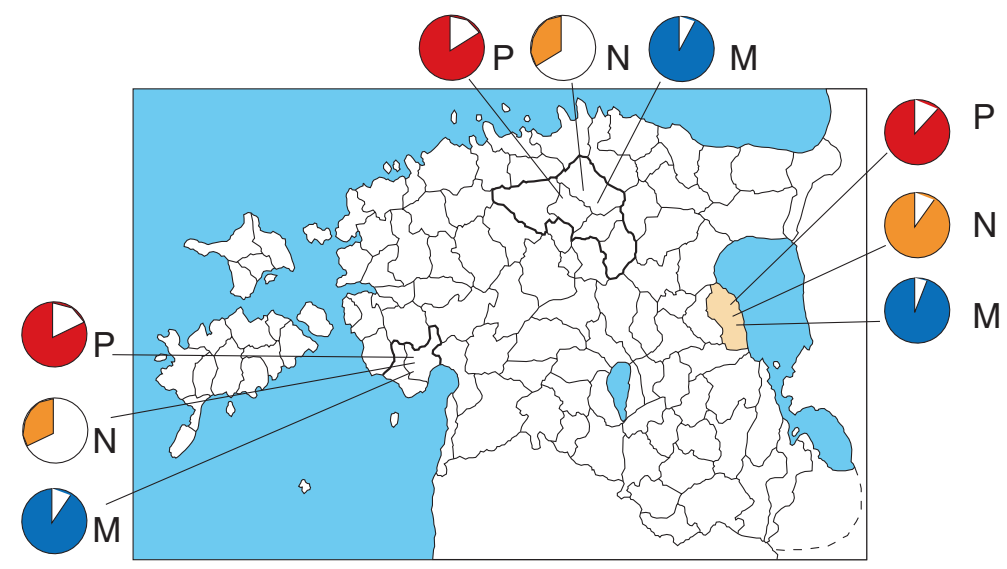

Figure. Distribution of the concrete person and location in the pajatusedtype tales $(P)$, jokes $(N)$ and legends $(M)$ of the Kodavere parish compared to other areas (results of fieldwork expeditions in 1964-1966). White sectors inside the circles indicate the number of texts of the corresponding tale type, where the element of the concrete is absent

The distribution map shows the relation of folk tales to a particular person or location in relation to the audience and compared to other regions ${ }^{3}$. The comparison included the total of 830 tale texts (excluding fairy tales for their low frequency of occurrence), recorded by the author on various fieldwork expeditions (Audru, Tõstamaa in 1964, Kose, Amble, Järva-Madise, Järva-Jaani in 1965, Võnnu, Põlva, Räpina in 1966, Kodavere in 1966).

It will be evident that the relation to local characters and locations, particularly in these tales, is far stronger in Kodavere than it is elsewhere.

\section{I}

Most of the popular tales about the locals of the area under discussion have been recorded only once. Still, it would be presumptuous to explain the small number of variants by the scanty collecting results or a small popularity of such tales. The issue is far more complicated for that.

It is characteristic of the tales based on the knowledge of the concrete that more than one tale has been performed about the 


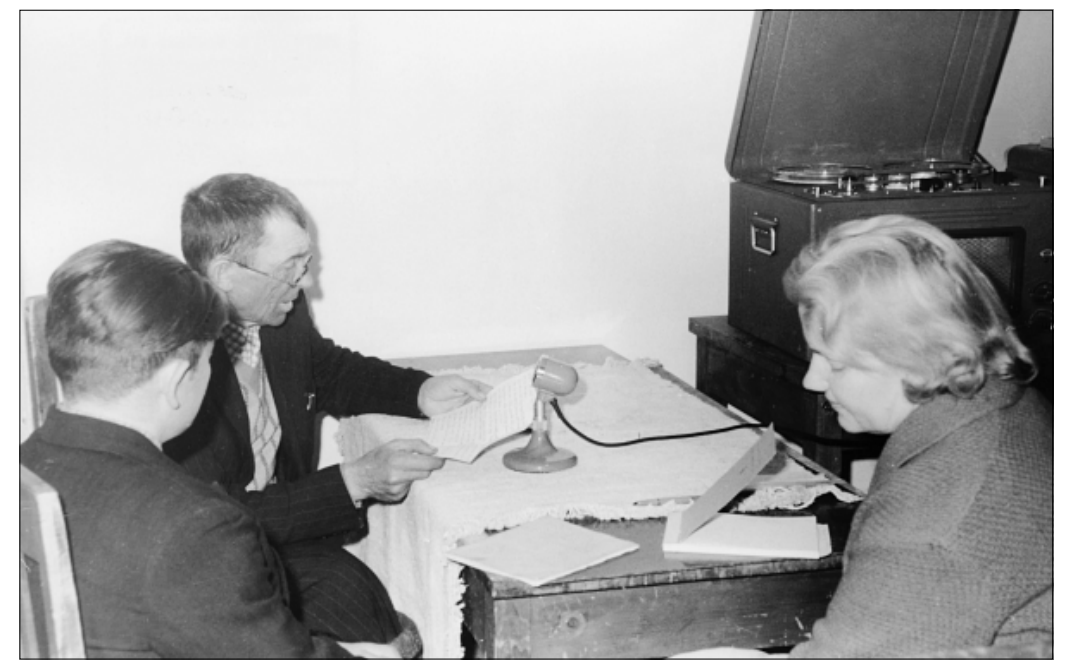

Photo 1. Selma Lätt recording Oskar Treial telling local stories. Oskar is scared by the enormous tape recorder and seeks support from paper. Photo by Richard Hansen, 1962. EFA photo no. 6196.

same event by more than one narrator. The tales may have several variants, but may have also been recorded only once. The fact that a particular tale is based on the knowledge of the concrete leaves the story-teller more freedom. The spread of an ordinary folkloric phenomenon is subject to the rule of self-regulation (Anderson 1923: 397-400): the narrator has heard the story on more than one occasion and from many different narrators, and passes it on without any significant changes. A folkloric material therefore retains its main form during spread. However, if an act of narration is not based solely on material heard from others, the teller may embed additional information about the familiar person, or elaborate on or even omit an episode, etc. while talking about an event associated with this character. Thus the influence of the principle of self-regulation can be largely ruled out and the teller is free to pass on his or her personal creation. The final form of the tale depends largely on the narrative situation, the type of storyteller (an improviser or a reproducer), and other factors. While narrating such tales to the local audience, the story-teller usually adds less information than is included while narrating the same tales to a non-local folklore collector. Obviously, the local listener already has the necessary 


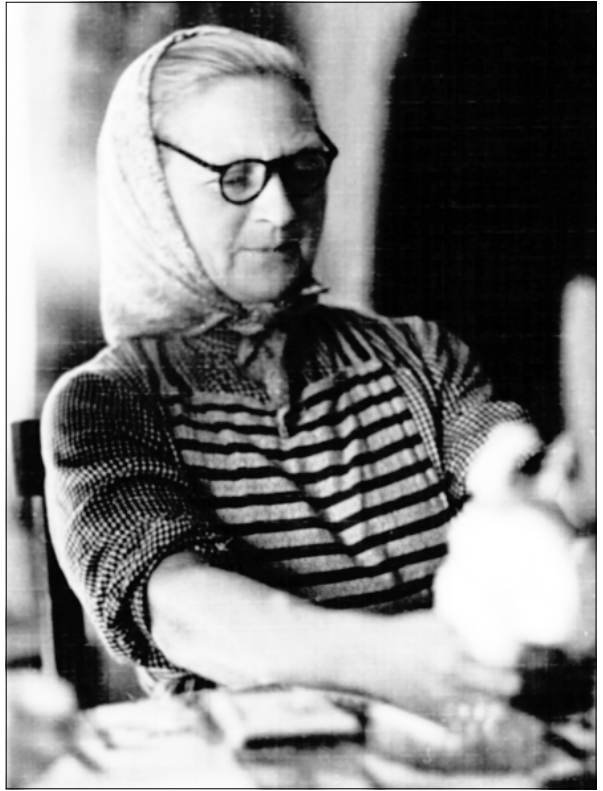

Photo 2. The narrator Leida Laasma. Photo by Richard Hansen, 1961. EFA photo no. 5229 . background knowledge. In the tales based on the knowledge of the concrete, the storyteller relies on the background knowledge as well as on his or her former performances. Story-tellers, who perform their tales more often (e.g. in case of Kodavere tales, Leida Laasina and Oskar Treial, who have both written down most of their stories) control their former performances better than story-tellers (like Aliide Ounap) with a narrower audience and random performances ${ }^{4}$. The former are generally more skilled at improvising and using structural devices. If the previous narrative performance about a specific event has been forgotten, the story-teller will easily adapt by structuring the tale differently. The following example is a tale recorded in 1947 from Leida Laasmaa ${ }^{5}$.

The Aarikes had a small family: mother, son August, and daughter Liisi. The mother likes to say that August is getting older each year, but the daughter will never turn twenty-five. They had much grain and firewood in store, but were stingy.

It was winter, and they started to make breakfast in the morning. But could not get water from the pail. Wouldn't come out. Mother says, "Liisi, dear, go fetch a log and crack the ice. Now fetch the potato basket and peel the potatoes. Heat up some water. Cut some splinters from the log, but be careful not to take too many!" The daughter heats the water. Potatoes are peeled, and mother tells the daughter, "Take the splinters from the stove, place them to the oven; put the frying pan with potatoes on top of them, this will heat up the room, too!" The splin- 
ters quickly caught fire. The old woman took and put the potatoes on the frying pan over the splinters and quickly closed the oven door. Stooping in the room herself. So she took knitting needles and sat on the oven seat, cursing the builders: why couldn't Kustu Anne Juhannes and the old Vaderi Vidrik make a house which rooms weren't damp and cold. Sat there for a long time. Then said, "It's quite warm already!" and touched the oven under her. Finally told the daughter to take these potatoes out of the oven, let's eat, and saw: the potatoes were all blue and smoking. Put these back on the stove and bring more splinters, Liisi dear. And saw the boys coming. Saw them, threw a bowl upside down over the potatoes. The boys were invited to the back of the house and were shown photos. The boys commended how handsome your husband was in youth. Mother told, "Yes, Joosep was very handsome in youth. I've never been pretty in my life, but Liisi takes it after her father." (Liisi was even uglier than her mother).

KKI 1, 97/8 (60) < Ranna - U. Mägi < Leida Laasma (1947).

Twenty years later I asked the narrator to tell me the story again. She claimed she had forgotten the story, because she had not told it in the meantime. In the later performance, it is the lady of the house who arrives, not the "boys". The tale was performed as follows:

There were huge stacks of firewood in the Aariku family. People there are very economising. A wealthy household. It is a cold winter afternoon, cold and stormy, as they usually are.

The housewife of Aariku household tells her daughter Liisi, "Go fetch potatoes, let's cook them in the oven tonight, will be nice and crispy," and we will heat up the oven, too - they had a good oven there that you could lie down upon.

(It was so long ago when I last told the story. Well, there was nothing more, the important thing was that they were stingy with firewood... Haven't told the story in the meantime.)

... The daughter peels potatoes, old Anna heats the oven. The lady of the house takes an aspen log, takes it, hacks off some splinters, stacks these in the oven, and sets on fire. The peeled potatoes are already on the frying pan and. The fire has been 


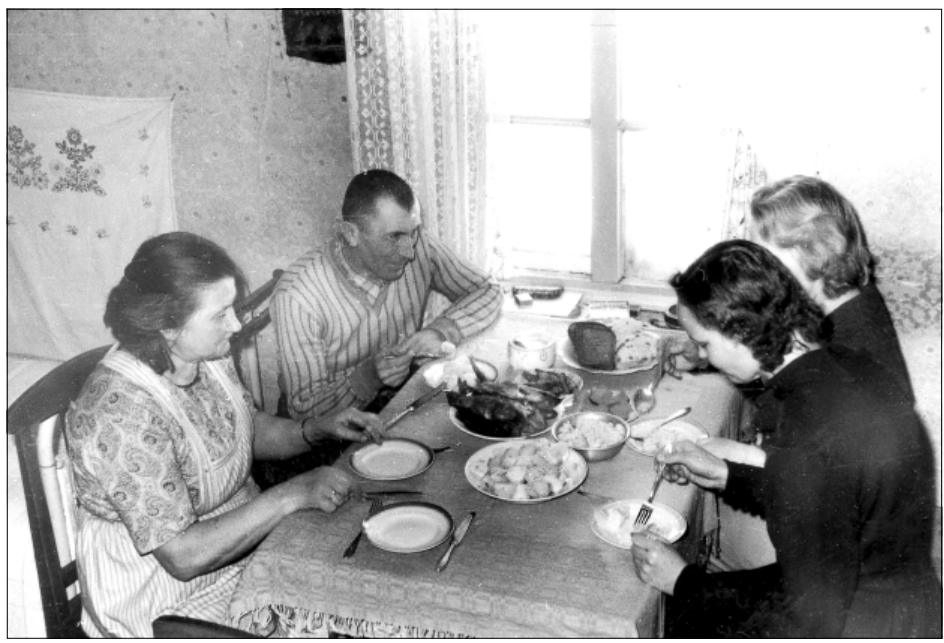

Photo 3. Folklorists are offered fish and potatoes in the Treials' home. Photo by Richard Hansen, 1961. EFA photo no. 6846.

burning for a while [-] and the oven doors, double doors, are slammed shut to keep the warmth inside.

Well, after a while the potatoes are put there in the oven and the oven doors are, again, tightly shut to keep the heat inside. And she herself sitting on the oven, knitting a stocking. Sits for a long time, sometimes touches the oven, no [imitates], "Is the oven warm already?" - But the oven was warm only at the spot where she had been sitting. Thought that, oh well, it will need plenty of time for it to get hot, I'd better go and see Jõe Maali. - It was not far away, right across the field. (These people were poorer, but more educated; the woman looked down on them. Maali's son was studying forestry. Karja Elmar, he was called.)

... Maali herself had gone down with meningitis. (Oh, by the way, Maali is still alive and well, but Anna died.) Tells Maali, "What's wrong with you, Maali, you will get rid of the earthly burden. But I have to remain here for such a long time." Maali was the lucky one: she [Maali] had meningitis and she herself was well! 
Having finished talking to Maali, she returns home in twilight, the time of house chores. Peeks into the oven, "Oh, dear! The potatoes all blue and not very warm and taste like smoke and tough and blue and raw!" Anna takes the potato pan from the oven and puts on the stove, takes the same aspen log and hacks off a few splinters, puts under the stove. Adds some water, places a plate upside down over the potatoes and starts boiling.

- And finally the cooked potatoes were on the stove.

I can't even remember how I told the tale twenty years ago.

RKM II 211, 582/6 (7) < Äteniidi. v. - M. Proodel < Leida Laasma (1967)

For being able to tell a story eloquently, the experience of a specific event, having heard of a character's speech, etc. is required; this, in turn, generates the experience passed on by the narrator over times. The teller is more reluctant to speak about the events that he or she is not familiar with, especially when there is another teller who can speak about it better. In such cases it is quite common that the teller refuses to tell the story and mentions another teller, who, reportedly, can retell it better, or the tale of another teller is embedded into one's own story. Since tellers are usually reluctant to tell the tales of other tellers, each teller forms a personal repertoire: such narratives are seemingly not traditional, as they are not passed on from one person to another, but they are repeatedly told by a single narrator. Oskar Treial, the best known storyteller of the Ranna collective farm, who can fabricate a story from any event, has mentioned on one occasion:

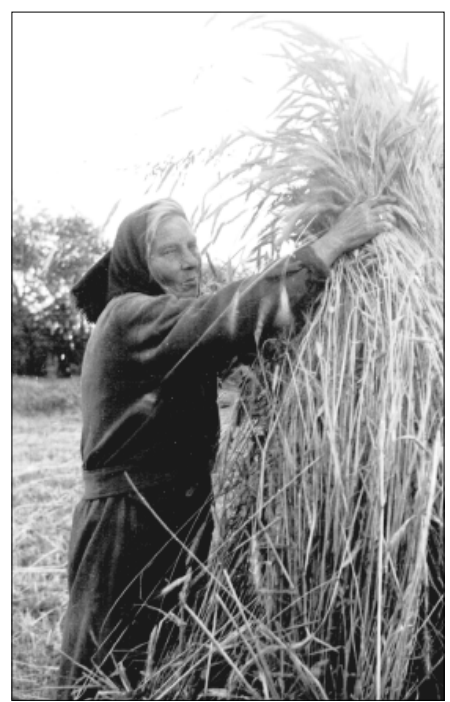

Photo 4. The narrator Aliide Ounap on her rye field. Photo by Mall Proodel, August 1966. EFA photo no. 7932. 
[-] I know and can tell the story, but Paju is so much better at telling the tale. When he speaks how they went to court with the herder boys [-], damn, how nicely he can tell it. I've heard him twice telling the story; I could never speak so nicely.

- How they couldn't get the gunpowder from the store, the boys kept telling that the cow is sick. When they had already got it, they still kept saying: "We need it for the $c$ o $w$, the cow is sick.

He will be more than happy to tell you how they went to school with Villem.

RKM II 211, 249/50 (58) < Raatvere v. - M. Proodel < Oskar Treial (1967)

The knowledge of the concrete and the experience the story is based on, on the one hand, and other factors, like the narrator's attitude, choice of aspect, interpretation, narrator's personal qualities, also the narrative situation and sometimes secondary information heard from others, on the other hand, determine the tonality of such tales ${ }^{6}$. Tales formed in this way usually remain in the repertoire of a single narrator, the audience alone will rule out any other performances. Estonian folklorist Eduard Laugaste has estimated the beginning of the tradition by a group's awareness of the first performer of a popular text: if the group has adopted the text, it is already established in the tradition. An attempt to determine the distribution area of such tales through questioning reveals that the tales are usually known in the area but rarely passed on, and at best, only a structure of the tale plot is given. In Metsanuka village on the northern border of Kodavere parish, for example, people reminisced at a social gathering:

[-] Or like Leida tells the egg buying tale, how [the saleswoman] couldn't count the change, so she counted and counted, told that when the husband comes home, then he will count.

These are all true stories. Nothing added or fabricated.

RKM II 211, 646/7 (4) < Metsanuka v. - M. Proodel < Paul Paju, 60 yrs. (1967)

Thus, the authorship of tales is acknowledged and people are used to hear the same tales from the same narrator? 


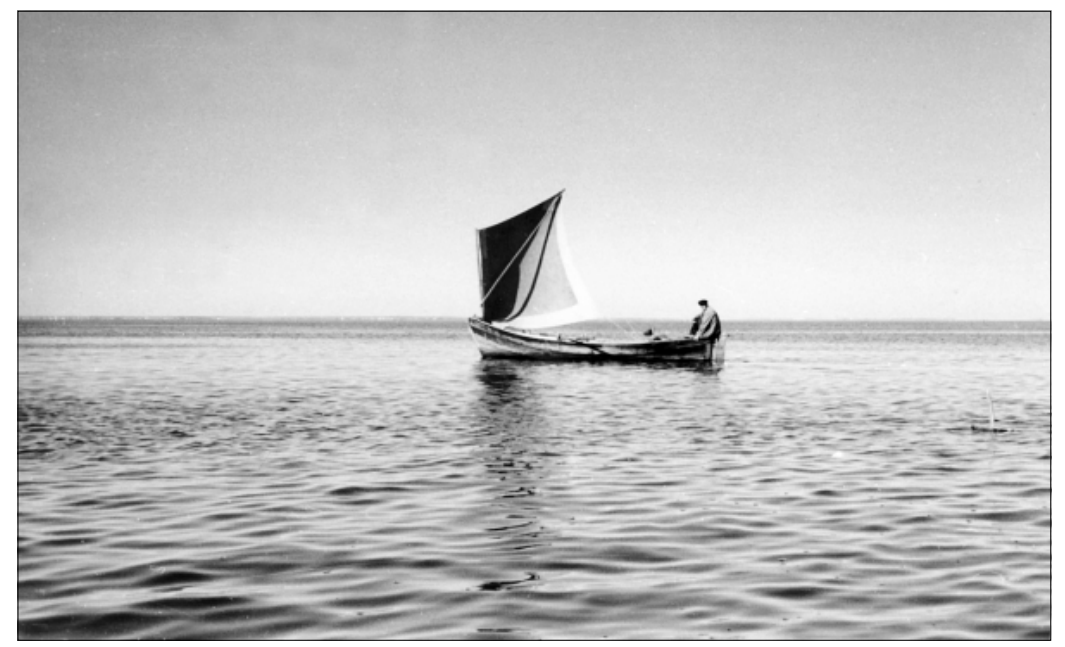

Photo 5. The narrator Johannes Otepalu fishing on Lake Peipus (Peipsi). Photo by Eduard Ertis, 1961. EFA photo no. 5538.

The tales under discussion are called folk tales. Would that be an apposite term? The tales are often individual creations, influenced to a certain extent by the attitude, evaluation and demand of the group. The spread of the tales is relatively narrow in time and space, usually not exceeding the range of the knowledge of the concrete. At the same time the telling of tales based on the concrete in the Kodavere parish (and elsewhere in Estonia, although to a lesser extent) is traditional, the themes and topics discussed in the tales are characteristic of other folktale genres (here legends, in particular), and even their function is the same. In these tales traditional structural devices are used. Consequently, this is first and foremost a folkloric phenomenon (cf. also Sirovatka 1961: 472-473). Such tales actually remain in the periphery of folklore and as such are of particular interest in observing the formation and representation of folklore.

The second group consists of tales where the concrete from real life combines with traditional folk tale motifs. These tales are characterised by a more elaborate structure and contents, and emphasise narrator's imagination; specific raconteurs are less prioritised in a narrative event than was the case in the first group. 
The third group of tales has a traditional plot. Presently, the tales of all three groups are in active use, although the most frequently told and most popular stories appear to be those of the second group: the tales where the concrete has been subjected to major reconstruction (thus making these less primitive); also, the traditional element closely associated with the concrete results in a greater aesthetic experience. While studying contemporary narrative repertoire in active use, it is important that more attention is paid to the tales of this group.

\section{II}

The material under discussion has been divided in three groups:

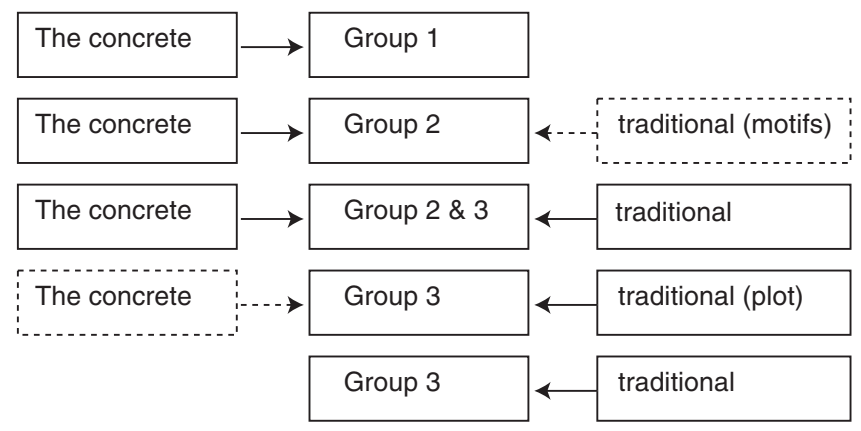

Group 1 starts on the borderline of description and narrative; the aesthetic value of these tales is increased by the stylistic devices of folk tales of a wider tradition. Most of these tales are the type called pajatused in Estonian. Next to traditional stylistic devices, group 2 is further characterised by employing the traditional motifs of fairytales, forming a periphery of traditional and non-traditional folk tales. Genre determination is considerably more complicated in this case. Group 3 consists of traditional folk tale types, whereas the genre specifics include the occurrence of the concrete in relation to the audience (such as, for example, local legends which are associated with a geographical location that the story-tellers and listeners both are usually familiar with).

Thus, the third group is formed of fixed folk tale types. While attempting to determine the types of the tales of the first two 
groups, it is useful to remember the definition by Stith Thompson: "The term [type] is used by folklorists to mark the ability of a tale to preserve its independent existence within the tradition. Each tale, no matter how complicated or simple, which occurs as an independent narrative, forms a type..." (Funk \& Wagnalls 1950: 1137-1138).

Let us observe another tale from this angle.

An old woman had three sons and all of them were unmarried. She herself was a widow. Lived in the Sääritsa village. This is over where Liide Ounapu lives. And eventually the boys got married.

Juhanes, the eldest, was the first to get married. The old woman screamed that "No, you shouldn't marry this one, marry anyone but her!"

The son, however, did marry his fiancée and the old woman was angry and very upset. Wouldn't even allow anyone to go visit them. This was the oldest son.

A few years passed. The younger brother was about to marry his girlfriend Miili. This brought about even a bigger quarrel. And, again, the son married Miili and. This was the younger brother Julius.

And the youngest brother was left. The old woman told about him that "I wouldn't let him, he is such a good son", that she herself would choose a wife for him.

Once, the old woman heard that the youngest son had been reading together with a widow, and he was gone, too. The others went before him; nobody could get on with the old woman.

And they start arranging for a wedding. The widow's house and the old woman's house were not far apart, only a little, a few steps away. - So they prepare for the wedding, but the old woman wouldn't let them go through with it, says, "I will hide the boy's new trousers." (My mother was there on the wedding morning, she knew what the old woman was up to.) So, on the wedding morning she took the boy's trousers and hid them, went to the beach and hid them between the rocks in the bush, that he should go with old trousers, if I have hid the new ones on the wedding morning. Then her son was also a musician, 
had a concertina, and she hid the son's instrument. Locked the door from inside and wouldn't let anyone enter.

But the horses were already gathering around the wedding house, to go to the church, but the new trousers are missing. He had got his other clothes in the morning - the jacket and the hat. So they start searching around the house and search and find the trousers at the beach, finding it very funny - the wedding guests really thought it as hilarious.

But how to get the instrument? The older people advise that "go and ask the old woman nicely, and she would open the door, and give back the instrument, and come along," but when the old woman saw that the boy had pants on, she saw red.

But the son knew a hole in the wall of the entrance room, and sees: the old woman has taken the concertina and is climbing up to the hayloft, that "let them break in the room, they cannot find it up there in the loft, I will take it to the loft." But the groom told the groomsmen to "jump to the roof of the pigsty and then to the hayloft and take the instrument from the old woman."

The old woman didn't even know that the boys were sneaking in from the loft hatch. See that the woman is hiding the instrument, that would wait until the old woman starts to go downstairs, that they will jump to her and take the instrument and go. And so they did. A groomsman took the instrument and left with it, the other one went to the ladder and shook it, so that the woman could not get back up. Shook the woman off the ladder, she fell on her spinning wheel. I don't know how high these ladders or lofts were, but the old woman didn't get hurt, but fell on her spinning wheel, hitting her thighs. The old woman started screaming that "Help me, good people, they are trying to kill me, an old woman!" The groomsmen took the concertina to the wedding house and started playing at once. All the guests were so humoured from these events that - as my mother used to tell - were watching the whole morning what the Jaan Tiva was doing again.

Well, the wedding was held and the old woman was living on her own, and later felt very bored and lonely, that she had pushed away all her sons and daughter-in-laws. Thought that would go to see the younger son. And she does. And tells them 
"Let me come and live with you, I wouldn't want to be by myself, and making firewood is also getting too hard for me." And "Let me come to live with you" And the daughter-in-law tells her "Well you come here, but you, mother, wouldn't want to be at peace," that "You will scold and." And "Heavens!" the old woman replies, "When have I ever scolded anyone?"

Well, and the daughter-in-law says that "Look how you called Viiu all these names!"

"But when have I called this lazy mare names?" That "Let me stay, I would rather sew my mouth together than say a bad word to any of you."

And the son and daughter-in-law let her stay. But the old woman couldn't express herself and fell ill - couldn't call names or scold anybody. Had lived there for one and a half months and fell ill. And said: "I will go back to my house."

Well, they arranged it so that each son would take something to her, flour for bread, firewood, so that she could live as she likes, old woman like herself and...

The woman's health grew even worse, and it was decided that the minister should be summoned to give her godly blessing. That she has been to the Communion all her life and may die before receiving godly blessing.

The minister was summoned, so he could administer the Communion. Asked before, "Dear Kadri, before you depart this world, do you have anything to confess" (like a sin or something), "then tell me your whatever is on your mind".

"I would have, minister," she replied. "I have always wished to boil and eat these purple potatoes that are growing under Mikura's apple trees."

"Dear Kadri," the minister tells her, "forget all these earthly matters. Soon you'll be where there is no cold or hunger. You will want nothing in the Heavenly Kingdom, the pearl gates and golden apples on apple trees and choirs of angels singing."

"I want no pearly gates or choirs of angels, if I could have a warm corner to sleep in; I am always cold in this hut."

On that the minister administered the Holy Communion and Kadri did taste all these bread and wines. Then she thought 
about it for a while and told: "Poor treat, that's what it was. Ane Märt's wife brought me a bowl of bean soup - that was much better."

RKM II 211, 481/9 (6) < Ranna - M. Proodel < Leida Laasma (1967).

The narrator comments on her tale: "Partly, she was right, the villagers did make up some things. But the wedding story and hiding the instrument and trousers, that was true. My mother had been invited to the wedding and she was there." (Ibid).

The same characters appear in altogether four texts from two narrators, who are familiar with the characters and have heard of the events from other participants in the events (mostly through family members). Depending on the narrator, the emphasis of the event differs with each narrator: either the storyteller emphasises the comical situations, exaggerates or remains truthful ${ }^{8}$. The last text, however, includes an episode with the minister and Kadri, where the dying woman craves for relatively material things. This is an anticlerical joke "What does a heart yearn on deathbed". Since 1895, seven texts have been written on the theme. In these texts the minister asks: What is it that your heart yearns? What is it that your soul desires? Is it ready to die or do you have something on your mind? What is the story of your soul? The answers are: The sick has a craving for something salty. A well-brewed kvass is left behind. Wants to taste spring potatoes before. Ounap's tale lacks the traditional ending of the joke, although there is an indirect allusion to the bean soup. More information has been given on card playing of which the narrator learned about from her husband.

The wife of Kaarel of Mardi Ants had three sons. Were living right here...

One played a musical instrument - had built an organ. This roared like a bear, what a noise it made. Played sheet music on the organ, but had no singing voice.

So the boys went there in the evenings, Aluks of Uudse and from another family, and the boys were invited together, to play cards and. 
Then two houses towards Uudse, there were two widows living, one was Kesa Miili and the other one Rootsu Reet. Reet was an old maid. And, well, Rootsu Reet and Kesa Miili were much older than the boys, twenty years older. These were such quiet boys, no drinkers. And the women wanted these boys. One chose Julius, the other one Jaan. And I don't remember who got who... Kesa Miili dated Jaan and Reet dates Julius. [-] And, well, these were quiet boys, and the women went behind their windows to call for them. And the mother was always so angry at the women that she always went to chase them off when they appeared at the windows again.

And then. They all had plenty of time at winter nights. The boys, again, gathered there and started playing cards, and two boys played cards and Jaan played the organ and. Julius played the concertina. He had a concertina, and the boys, again, on a winter afternoon, again - went there every night - went there to play cards. Other players always cheated on Julius and Jaan. And Aleks of Uudse saw how angry the old woman was: that her boys are stupid and did not know how to play cards. Aleks sneaked out of the room so that the old woman didn't even see him, and went home and pulled on his mother's scarf and skirt, and comes to the window, quietly peeping inside. The others knew that Aleks was going to do that - so the others were in the joke. One player said to the old woman that "Look, Miili and Reet are at the window!" And the old woman took the poker - a poker with a wooden head - and rushed outside to get Miili and Reet, except for it was Aleks of Uudse, who ran around, crawling from laughing, around in the yard, the old woman coming after, terribly cursing. And the others were laughing in the room and the old woman couldn't get them - Aleks, that is, and was still thinking that there were Miili and Reet, and. And comes inside, fraught with anger, scolding her sons that if you, fools, don't know how to play cards, then don't, and sent everyone out, threatening with the poker. (That Julius lives here right near the manor.) Sent the village boys out.

And in the meantime Reet and Miili treated the village boys with vodka, and the village boys took Julius and Jaan over to Miili's and Reet's place, otherwise they couldn't go. And then, when they finally sneaked to the minister of Kodavere 
to read out. And when the minister announced them in church for the first time, the old woman went and withdrew the announcement: she wouldn't allow them. But then Reet and Julius and Miili and Jaan went to see the minister and explained that they were full grown men, and the minister allowed them to get married.

And, well, when they returned from the marriage ceremony, the old woman was beating the sauna roof with the poker [cursing] that he [the son] would grow blind and the other one wouldn't be able to eat or shit. And then the boys went to live with the women, and, well, the old woman was left to live there in the sauna alone.

And there was nobody, this old woman, to look after her, and she became quite weak, and there was nobody to make food for her, and Tossu Miili went to see her, then she asked for bean soup.

And this is how the mother's cursing worked. Jaan received enema all the time and Julius remained, blind for 25 years, is still living in the first house from the crossing towards Raatvere. Jaan, he is dead already.

Karla [the narrator's husband] has told for hundreds of times about the pranks they made. He was there playing cards with Jaan and Julius.

RKM II 211. 426/33 (3) < Sääritsa v. - M. Proodel < Aliide Ounap (1967).

Two of the texts under discussion contain elements of traditional folk humour ${ }^{10}$. To a certain extent this may be a case of contamination, although the tale cannot be identified as a popular joke, which is an independently occurring narrative type. This is because here the focus is on the quarrelsome Kadri and her conduct, and the conversation with the minister is presented only as a single episode in Kadri's life and the anticlerical function of the pastor jokes is secondary. However, the corresponding type in the joke type register should certainly include a reference to this text. Here is another example of the text recorded from Leida Laasma.

The wife of Mardi Antsu Kaarel, when she was about to die, all the other old women consoled her. Summoned all the neigh- 
bours at her deathbed. One woman told that you are not that bad off, Mardi Antsu Kaarel's wife, you can soon go breathe in Jesus' world. Another woman [said] that you will leave all the worries of this world behind. Kaarel's wife listened and said: "You're all such a poor consolation. But, look, the wife of Ane Mart came and brought bean soup in a bowl!"

So they brought soup. Ate up a bowlful of the soup and died.

KKI I, 94 (56) < Ranna - U. Mägi < I.eida Laasma (1947)

The presented variants cannot thus be considered as representing the type of anticlerical jokes, even though four out of the five texts include a minister among the characters.

Another question is whether these tales might form an individual tale type? Narrators of these tales claimed not having heard the tales from each other. Neither of the narrators had obtained additional information from different sources. Consequently, the texts recorded from A. Ounap and L. Laasma cannot be considered a single type, as their genesis is different - the texts have been created independently from each other (cf. Rüütel 1969: 9899). The texts are, thus, rather parallel types of different genesis. In the above example, the tale by Laasma has elements of a joke, while the ending of Ônap's tale resembles a legend.

It has already been noted that one narrator usually performs his or her story repeatedly. The audience is familiar with the story and demand its repeated performance, but never pass on the story themselves. Can the variants of a single narrator be considered an independent tale type? Probably not, as the same narrator may narrate about the same event with great variations. What we might be seeing here is the formation stage of a tale type.

Estonian scholars have divided the development of folklore in three stages ${ }^{11}$. The transition from one phase to another is never abrupt or without prior symptoms. For example, it is evident that during the transition from the first stage to the second, a folklore text becomes fragmentary, the sphere of use gets narrower, etc. The examples given here reveal that a folkloric text is not necessarily adopted in active use, and first undergoes a genesis stage. The tale plot and structural components of the tale 
may gradually form only as a result of informational reports mediated by several persons. Also, a single narrator may complete the tale's contents and structure only after a number of performance situations, and the tale begins its collective spread and becomes a collective creation in the general sense of the term only after it has acquired a certain artistic level and completeness. Even a factual description may develop into a spirited tale after a series of repeated performances. A specific tale performance may therefore be categorised according to a single characteristic feature as a work of folklore, and if it happens to be of high artistic value, it can be considered an artistic creation, which, at the same time, is not very traditional. I have noticed that such a phenomenon is particularly common to the tales of group 1 . In these tales, the audience is used to hear a particular story only in the performance of a particular person (often the author of the tale), and the tale is only about to enter the tradition. In the genesis stage the tale may therefore be in the periphery of folklore and there is no abrupt clear line between what folklore is and what it is not in this case.

Ruling out the possibility where a work of folklore (narrative) is generated by fantasy, and considering the line of formation where the tale is based on the knowledge of the concrete, the particular ways of forming a new tale type would be the following. A tale may be based

1. imminently on the knowledge of the concrete

2. on the knowledge of the concrete and descriptions provided by other persons,

3.-4. in addition to the previous two, on tales heard from other narrators,

5. (relying on the knowledge of the concrete to a certain extent) on tales heard from other narrators.

This also points to the creation's becoming more collective and entering the tradition. The following chart shows the knowledge of the concrete (in an oblong rectangle) and the performance of different narrators (in squares). The arrows indicate various possible associations between these. The first possibility shows the formation of parallel types of different genesis. 
1.

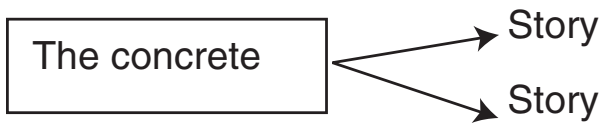

2.

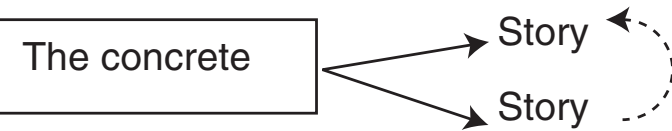

3.

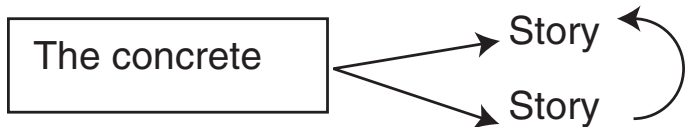

4.

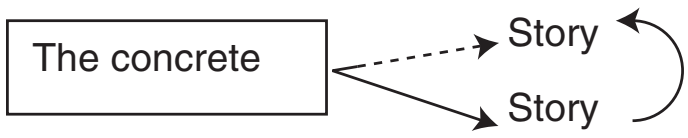

5.

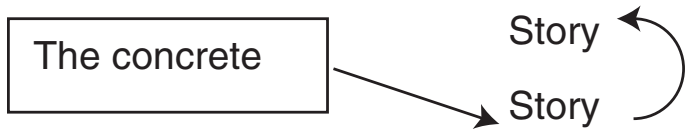

To conclude, the less a narrator relies on the knowledge of the concrete and the more he/ she relies on the previous narrations of himself/herself, the more folkloric a tale is and the more it has the characteristics of a tale type. Concurrently, the more definitive is the role of traditional motif(s) in a tale plot, the more it seems to belong among the traditional folk tale types and the more can the element of the concrete be considered secondary.

In the above examples recorded from Laasma, prominence was given to the knowledge of the concrete in the first example and the traditional pastor joke was secondary. Also, it is likely that the tale, which was intended as creative, formed on the basis of the event already in the repeated performance of Laasma's parents; she had heard the tale from her father and mother who had both been excellent storytellers. Without the first-hand experience (folklorists usually have very limited chances for that), it is impossible to determine the tale's stage of formation; it is, however, possible to consider the general regularities of the formation of analogous types.

The varying level of typological formation is nothing new in folklore. This occurs in different thematic passages of folk verses in 
Kalevala metre, in the song repertoire of different regions, and in folk songs emerged at different periods (Loorits 1940: 52; Laugaste 1946: 479; Pino 1964: 35-51). An ambiguous type or the lack of type has also been associated with an inchoate formation stage of the tradition, or with the disappearance of the tradition (Kolk 1959: 70; Tedre 1964: 8, 32). In the area under discussion, however, the tales (pajatused) are not in the inchoate stage or about to become obsolete. The tales discussed here are in active use even on present day, and not performed only at folklore collector's request. While the fairy tale tradition was disappearing, and legends and less topical jokes were about to fall into oblivion, the significance of humorous Kodavere tales in the folk tale repertoire increased, whereas the tradition of telling these tales is still actively in use. It is also noteworthy that some of these tales resulted from the degradation of traditional folk tales (see also Proodel 1967: 281-285).

Generally speaking, the occurrence of a tale type in formation stage is a rule and may also be considered characteristic of the type. Another characteristic of these tales is a narrow spread in time and space, so that often it is impossible to talk about collective circulation. At the same time it is fairly possible that the local tales exceed the limits of their narrow spread, although very rarely, and evolve into specific types (especially, for example, the sayings of the locals in a specific situation, which, if forming into a narrative, may become the pun of the joke). This is one of the formation possibilities of a folk tale type. While spreading in time and space, the tale is associated with what the local audience considers the concrete, this is something that can be quite commonly perceived in folk tales. Since most of the types are in formation stage, the compilation of an exhaustive type register of the pajatused- type will prove impossible, even though so far most of the pajatused tale types of wider distribution area have been registered (though categorised under other tale types). The material studied here definitely employs traditional themes. This type of tales has its own thematic limits which are determined by the temporal and spatial scope of its existence.

Along with the gradual disappearance of many folkloric phenomena, the tradition of story-telling is also on decline. In towns, the period of disappearance of the narrating tradition has been con- 
siderably shorter, the cultural advancement of people so much faster and the speed of life so unfavourable for telling humorous tales that the telling of pajatused-type tales can now be associated only with rural areas. Even tales told at workplace are much more common in the countryside than they are in towns. The themes of the tales, of course, are inspired by the surrounding environment.

The Kodavere parish has been an extremely favourable area for finding new narrative themes. The farms are situated closely in the villages and villagers were well aware of their neighbours' lives. Freeholders were directly dependent of the will of landowners, and little in their lives was left secret. It is told that:

Vommilinn was the settlement in Sassukvere village, Tinalinn located in Praagamets. Like there was Kukulinn and Palalinn and Karulinn. Farmowners allowed the poor men some land in the outskirts of their premises, at the edge of swamps. Quite many of them gathered there at the swamp like that. This arrangement was also useful for the farmowners, as they got farmhands and day-labourers from there, they went to look for them at the swamp.

They also had different level of education. Those living at the swamp were not educated and were the butts of... all these jokes and their life - their religion, pugnacity and education. [-] There were all these stories about the people living at the swamp. [-] Usually they came to complain and find help at the farm, the people of the farmstead listened to the tales and passed on.

RKM II 211, 498/9 and 507 < Ranna - M. Proodel < Leida Laasma (1967).

The choice of tale characters reflects social relations. The haughtiness and avarice of the rich was often ridiculed. Next to economical hierarchies, the main theme of the tales has been cultural backwardness ${ }^{12}$.

That the narration of episodes from the lives of specific persons has been traditional is indicated by the fact that analogous tales have been recorded from twelve different informants in Kodavere. Here is a shorter example of a character portrait. Evidently, the 
narrator need not have invented the story, but passed on a true event, perhaps even imitating the style of the main character.

Kuusiku Kuarel

We had a large hayfield, four slash-and-burn fields and six halfacres of land near Viitke. Kuusiku Kuarel tended them, Kuarel was supposed to work as a day labourer there.

Miini was sent to fetch him. It was haymaking time. Went to call him that:

"Come to work!"

"Oh. Have got no time, have swaths to make at my field. I'll come to sheave rye!"

Rye-making time was approaching. Father sends for him.

"Can't come, Piädi needs a hand to sheave rye together, I was just asked. I'll come to help at summer crop, at summer crop harvest!"

So I went to ask Kuarel to the harvest of summer crop:

"No, how can I do it now! Can't! Have to harvest my own summer crop. Will come to harvest potatoes with Juula, potatoes!"

Wouldn't even come to harvest potatoes. I went to fetch him:

"Come to pick flax!"

"No, can't do! Can't do at all, health is failing. I'll bring fish in spring, fish."

In spring he said:

"Had there been as many fish as there were last year. No more fish left in the river, no more fish."

ES, MT 289, 24/5 < Alliku v. - A. Univere < Jakob Luka, 52 yrs. (1940).

This story belongs to the first group: it is based on the knowledge of the concrete, while the theme is traditional. The analogous tales condemn the same human characteristics - namely, laziness, stupidity, avarice, greed, lack of education and untidiness - that are condemned in fixed joke types.

The tales where the focus is on a particular person are as popular as those that centre on an event and which characters are 
secondary. The most common tales of this type have no particular focus and can be called neither personal histories nor situational tales.

As in jokes, the tales based on the concrete discuss the relationships, courting and weddings of young people. Quite a number of tales tell about local social figures, most often about manor owners. Like elsewhere in Estonia, the tales talk about eccentric village beggars, often as people of extraordinary physical or intellectual abilities; such tales often contain folk tale motifs of a broader tradition.

The number of clerical tales is truly remarkable: these tales discuss the church and the clergy, Lutheran pastors, Russian Orthodox priests or sectarians. Nearly half of the joke repertoire in the Kodavere parish is clerical jokes, among which most of them are closely interrelated with the concrete. Humorous stories have also been told in connection with church ceremonies, especially at Baptism and death wake. In the area, gatherings to death wakes and placing the dead in the coffin became a social event for the youth, who told tales, sang folk songs and entertained themselves during the wake.

Many of the tales talk about life in the past. More than twenty recorded texts discuss the injustice of the manor. Other topics included former living conditions, unusual events, customs, beliefs, forms of entertainment, first settlers. The Kodavere settlement dates to a relatively recent period (see e.g. Moora 1964: 5964) and former life is often described in oral family histories. These tales remain to the borderline of the pajatused-type tales and legends. Here is a comparison of two texts:

The upper corner and the lower corner of the Assikvere village. The fields of the owner of the upper area were very straight. And a good these had, blue clay beneath and rich black soil on top, not bad at all. We had sand. There was this old thick forest here. Kualike Juan built a house in the woods, this lad here [the narrator's grandson] is the seventh generation. Kualike Juan [founder of Oti-Kaalika's farm in Assikvere] worked at the manor as the cabbage grower, was so loyal to the landlord that the landlord built him a manor house. Where Vashka is now [Vashka farm on the edge of the forest north of 
Assikvere], first the house was built over there, was ready. Afterwards thought that this place was higher. So brought the house up here.

My father was a corvee there. Horses were so worn out that fell over on the road. Near Linnamäe a fox came along, was playing right under the crock's nose. The horse was lying down. The man was given thirty strokes with a rod because the horse was so worn out.

ES, MT 288, 29/30 < Assikvere v. - A. Univere < Jakob Otisalu, 76 yrs. (1940)

The theme in this example is rather traditional, but the tale describes a local object. Here is another text, where the storyteller recounts his family history. These tales, or to be more precise, tales of these motifs, are usually preserved within the tradition of a single family.

The Reili family comes from Germany, were brought here from the Rhine. The owner of Sootaga manor exchanged two borzois for two men, who now are the forefathers of the Reilis. KM KO, f. 199, m. 43, 75 (5) < Kodavere v. - M. Ehrlich $<$ Mihkel Reili, 80 yrs. (1929).

This appears to be a folk tale type where the traditional motif exchanged dogs for men has been associated with the concrete ${ }^{13}$. Analogous tales have so far been discussed under historical legends (cf. also Simonsuuri 1951: 15ff). The tales, however, lack any mythological element, and would not therefore fit under the definition of legend. Quite similar are recollections about past wartime, unjust landlords, name giving. A fair number of such stories discuss toponymy. Even these tales are often based on the knowledge of the concrete; they are more or less fixed as types. The position of such tale texts under tale types is bound to be somewhat mechanical, as these are all traditional tale forms. Consider, for example, the three following tales, which appear to be based on a specific unusual event, which has been imaginatively elaborated on.

1. There is the so-called Kooljamägi, or Death Hill near the well-known "Kalevipoeg's bed" in Alatskivi. People talk about the name as follows. Children were sleighing on the hill. 
One child accidentally fell in front of the sleigh and the sleigh ran over its body, cutting the head off. The head remained to one side of the sleighing path, the body to the other side. The head said: "Don't want to sleigh anymore!" That is why it is called Death Hill. ERA II 250. 291 (1) < Peatskivi v. - E. Ratassepp < Kaarel Ratassepp, 55 yrs. (1939)

2. When I lived there people went there sliding. We had stopped singing. My parents were good singers. In Pusi, our home village, the bank was sloping downward at the river, we went sleighing there. Not everybody had a sleigh, so we took wooden logs and slide on these.

There was a major sleighing, so that a large sleigh ran over one's neck and tore the head off. The head was even saying: "Who has the sleigh, who has the sleigh, who has the sleigh!" This is what the parents of my parents told. RKM II 48, 105/6 (17a) < Torila v. - S. Lätt < Sohvi Sopp, 83 yrs. (1954).

3. My father-in-law's sister told that when they were sleighing one night here in Naelavere, I don't know whose hill it was, a sleigh was full of children. The sleigh was pushed downhill and a young boy fell off and was caught under the sleigh and the head came off. The head rolled away and said: "La-la-la." It happened before I was born, around 1880. RKM II 83, 580/1 (122) < Tartu-Maarja < Kodavere, Kadrina v. - J. Põldmäe < Aline Oras, 60 yrs. (1938)

Tales about witches, wise men, witchcraft and healing are also closely linked to the concrete. This often results in type variation, instability and ambiguity, representing the border area of pajatused-type tales and mythological legends. This perspective also explains the issue of memorates.

Memorates are not a separate folk tale category (cf. Tedre 1965: $64)$; and by no means can they be equalled with pajatused-type tales. A memorate is first and foremost a recollection, subjective impressions of reality. Memorates as descriptions of personal experience have been studied separately from mythological legends (e.g. Sydow 1948: 73-74). Folklorists have proceeded from the presence of a belief or a religious motif and have categorised such texts under legends, regardless whether the texts include 


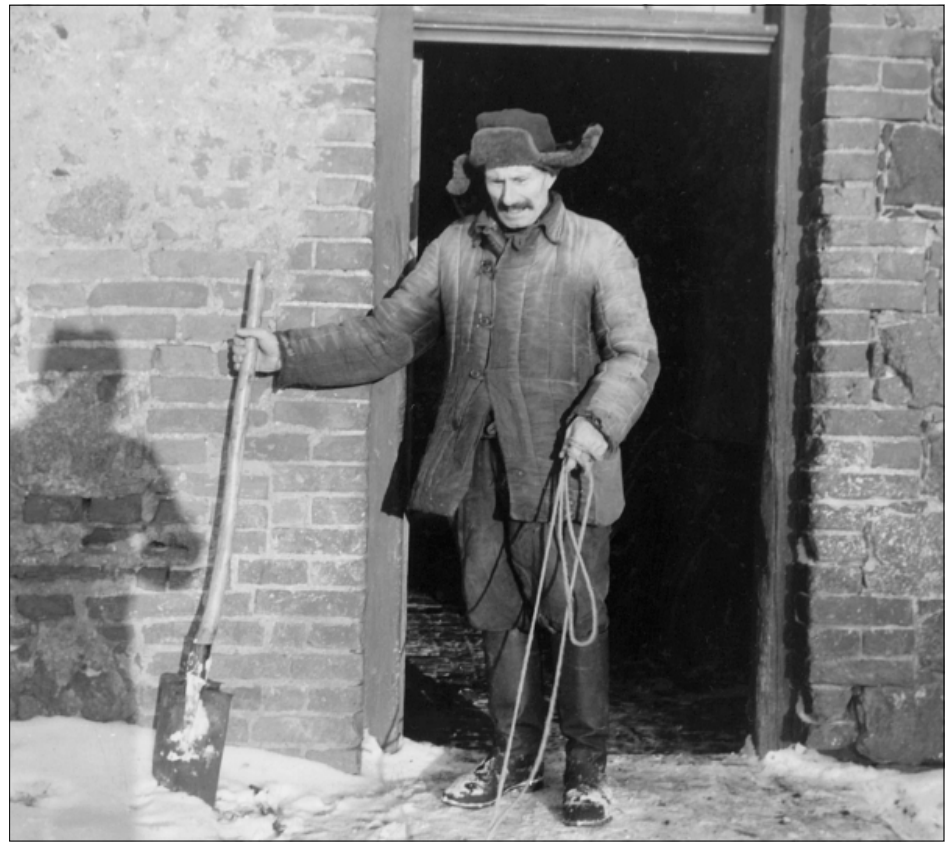

Photo 9. One of the prototypes of local stories, Salu Eedi, in winter fishing clothes. Photo by Mall Proodel, Jan. 1967. EFA photo no. 7978.

the personal experience of the narrator and his/her relatives or not. In these tales the beliefs of the broader tradition have interrelated with the concrete experience, and as such the tales remain in active use in a narrow area. A narrator may actually be seeing ghosts, if s/he believes in them, and pass on the personal experience in great details, so that the tale clearly manifests the knowledge of the concrete. A narrator may just as well leave out details and pass on only the most important points, so that the first person perspective functions only as a stylistic device serving the purpose of credibility. In sum, memorates based on a belief are legendlike in the sense that they contain the mythological element, and are pajatused-like in the sense that a belief forms into a tale (memorate) only via the mediation of the concrete. Personal experiences and recollections can be passed on in the form of a legend or a pajatused-type tale (in the former case a tale includes the mythological element, in the latter case it 
does not). While pajatused-type tales as an individual folklore genre have been hardly ever discussed in the Estonian folklore studies, some attention has also been paid on recollections that do not incorporate elements of folk belief. In modern times even these are more common than those tales that incorporate the element of belief (this also applies to regions other than the Kodavere area).

While the legends differ from pajatused-type tales in the element of mythology in the text, the differentiation between pajatused and joke is much more complicated, as both are essentially humorous tales ${ }^{14}$. The following text example demonstrates the narrator's strong satirical attitude towards a clergyman; the missionary is heavily ridiculed, but the story is still not a joke:

And then there was this tale, I don't know whether you want to put it down. It happened here near the sauna, where Kettunen used to live.

Kaelu was already old and wanted to pray. And from Assikvere ... Nässi Joosep, he was the church man. So he came here on Sundays to hold a prayer meeting and all the villagers came together. Some even came from Omedu to attend the prayer meeting. And then Joosep... and all the village boys came here, the whole bunch came together here. To play pranks and tricks. And then Joosep stepped at the table and announced the psalm that:

"Oh, you inspirer of life..." and a boy shouted from the back of the room, “...and driver of people."

And the younger people sang to Nässi Joosep's lyrics, while the boys sang to what one of them had said. And ... but Nässi Joosep took it quite well, wouldn't cancel the prayer meeting and the boys saw that there's no point in doing that. Joosep keeps on talking and...

And then they remembered that Joosep had this very furry papakha, like a Russian soldier's hat, hanging in his kitchen. And then Kaelu took soot from the oven and smeared this white hat black. And then Joosep had this worn-out white jade tied to the willow tree. And Aleks brought soot from home and 
dyed the horse black. Then Kaelu put some big fisherman's boots on the horse.

The old man ends the prayer meeting and wishes everyone an interesting reading the next time, so that everybody would come, and starts off, looking for his hat. His fur coat's sleeves were filled with tar. Kaelu had this tar pot. So he says that he will first put on the hat and then the fur coat. Starts looking at the hat that this is not his, he didn't have a black hat. Searches through the place and would even tear Kaelu's house apart, cannot find it. Finally realises that the boys have taken his white, exchanged his white hat. Well, so he starts putting on the fur coat, arms all smeared with tar and the fur all smeared. And then began to swear - first prayed to god, then started to swear. Then he cursed. Couldn't even put mittens on, or they would be smeared with tar, too. So he washed his hands, and goes, puts on this hat, which has been smeared black - must be swapped, nothing to do, and goes on to look for the horse to ride home and it's already dark and. And, well, sees that there's a black horse instead of a white one! Began screaming like hell that now the Old Nick has taken his horse and given him a black horse in return while he was holding the prayer meeting. And sees that all the harness and headgear are his, but the horse is not. And then decides that he will go to the police the next day that his has been taken and exchanged with another horse, that his used to be stronger and now there's this jade. Starts off, unties the horse from the tree - from this willow -, the horse's shoes fell off! The old man was very frightened, what will happen now, can't go anywhere, the horse's shoes are loose!

Finally the old man realises that the horse was standing on its own feet, and started off that will see tomorrow, will look for own horse then. After he got home, the next day, started to look that this was still his own horse - had some white spots under the stomach and.

After that he never came to hold a prayer meeting here; although he used to come here for years each week. In some periods there were so many of these missionaries.

RKM II 211, 433/9 (4) < Sääritsa v. - M. Proodel < Aliide Öunap (1967) 
As in a pajatused-like tale, the events of the joke originate in real life, which further complicates the distinction between pajatused and jokes. The folk humour files of the Estonian Literary Museum contain a large number of pajatused-like tales. It is also noteworthy that nearly half of the joke repertoire of the Estonian folklore archives is single texts, which traditionality is difficult to determine (Krikmann 1965: 21). Pajatused are very likely these singly occurring tales, as it can often be assumed that the tales are based on the knowledge of the concrete, the plot is not known in the wider tradition and there is no fixed tale type (the occurrence of true stories in the Estonian joke repertoire is discussed in Põldmäe 1941: 8-10). A comparative analysis of a large number of joke and pajatused texts should reveal various compositional and other differences, which deserve further study. Pajatused are distinctive from jokes also for the combination of various important characteristics.

Above I have discussed the formation of folk tales with a strong connection with the concrete in relation to the audience (a concrete person, event, setting) in the Kodavere area. Tales based on the knowledge of the concrete are particularly characteristic of this area and have been preserved in active use until today. The tales are based on real life facts, but share a narrower distribution in time and space.

The fact that a narrator relies on the knowledge of the concrete and not only what s/he has heard from other narrator(s), leaves him/her more freedom during a narrative situation. Narrators who tell their stories seldom and more randomly often rely more on the concrete, whereas people who are more talented and skilled storytellers have usually performed the same story more often and repeatedly and employ their previous narration experience more frequently. A narrator usually refuses to tell about the events that $\mathrm{s} /$ he is less familiar with, particularly if there is another narrator who would tell the story better. This leads to the formation of a unique kind of authorship and the tales seemingly exist outside the tradition. The formation of such a tale is determined by the knowledge of the concrete, the narrator's attitude, interpretation, narrator's personal characteristics, also the narrative situation, and often also information obtained from others, on the one hand, and the audience's attitude, evaluation and de- 
mand, which also determine the tale's acceptance in the tradition, on the other hand. The narration and structural devices of these tales are usually traditional. Thus it is first and foremost a folkloric phenomenon, although the role of individual creation here is much more important that in traditional folk tale types.

According to the degree of the concrete in the tales, the tales could be divided in three main groups:

(i) tales based on the knowledge of the concrete

(ii) the concrete + traditional motifs

(iii) traditional plots (which may be associated with the concrete during their spread).

The majority of tales belonging in the first group are pajatused, the second group consists of the periphery of the so-called traditional and non-traditional folk tales (determining the tale genre is the most complicated aspect), and the third group consists of fixed folk tale types.

In terms of the typological aspect, it could be said that

(i) the tales of the second group incorporate motifs of fixed tale types in the tale based on the concrete. This does not mean that the tales could be categorised under a tale type with a broader tradition, if the focus is on the contents based on the concrete and less on that borrowed from the wider tradition.

(ii) even though there may be tales about the same events but performed by different narrators, these tales do not form a separate type, as these are often created independently from other narrators. A more apposite term for these tales is parallel types with different genesis.

(iii) the narration of an informant telling about the same event may vary considerably, thus even the different performances of the same tale cannot be considered type variants, and rather represent the formation stage of a type. The less a narrator relies on the knowledge of the concrete and the more s/he relies on his/her (or other narrators') previ- 
ous performances, the more folkloric a tale is, and the closer it is to be considered a tale type.

(iv) the occurrence of a type in the formation stage is a rule and a characterising feature of the tales of the first group. These tales typically have a narrow spread in time and space.

The concrete incorporated in the Kodavere tales is borrowed from the surrounding village life. The tales where there is no special emphasis on a person or an event and are neither personal nor situational tales in contents are more common. Tales of the first settlers, etc, are passed on from one generation to another in the form of oral family history. These tales remain in the periphery of pajatused and legend (tales of the second group). Peripheral are also recollections about past wars, name giving, evil landlords, etc.

Another borderline group of tales are memorates, which include religious elements and concrete experience: this combination ensures the continuance of a tale within a narrow area. The most problematic issue at this is making a distinction between pajatused and jokes. This question (and all the other issues discussed in the above article) could be more exhaustively answered by the study of folk tales in close relation with their narration and the study of narrators.

\section{Comments}

1. The tales included in the folklore archives of the Estonian Literary Museum, the Institute of Language and Literature, dialectal archives of the Estonian Language Society of the Estonian Academy of Sciences, and the folklore archives of the Chair of Estonian Literature and Folklore at the University of Tartu. The first tale text was recorded in 1852 (ÕES, SK $96 a, 1 / 14)$.

2. The 1939 campaign for collecting legends yielded $1 / 6$ of the total number of recorded Kodavere tale texts. More than half of the Kodavere texts are legends.

3 . This association is grounded on certain probability. Since comparative material is scarce and tales have been collected with a specific thematic 
emphasis, the map only shows the ratio of different areas rather than the general distribution of the repertoire at given locations.

4. During 1947-1967 the total of 161 tale texts were recorded from Leida Laasma (b. in 1907, Äteniidi v. Ranna settlement) and during 1961-1967 the total of 107 texts (excl. sound recordings) were recorded from Oskar Treial (b. in 1901, Raatvere v.). In 1966 and 1967 sixty tales were recorded from Aliide Õunap (b. in 1900, Sääritsa v.). For further information about the informants see RKM II 48 and RKM II 211, fieldwork notes.

5 . On request of the informants the names of people in the tale examples have been altered. In order to avoid tale prototypes, narrators often omit the names of the characters during narration to a folklore collector, less frequently other names have been used.

6 . Dependence on the storytelling skills, which determine whether a particular event is passed on in the form of a description or a tale is emphasised by Neumann (1966: 184).

7. The presence of authorship is common among more primitive societies.

8. Neumann has characterised the formation of a tale very aptly, "The more dramatic or comical a narrated event was, the more it tempted the formation of the narration, and the easier the formation was." (Neumann 1966: 184)

9. Type number 54 in the register of anticlerical jokes in Estonia compiled by Raudsep (1969: 57-58)

10. The second one - RKM II 48,479/83 (5) < Ranna - S. Lätt < Leida Laasma (1955 is not included here.

11. The division by E. Laugaste, where stage 1 marks the active use of a work of folklore, stage 2 the loss of active use, when the work of folklore is remembered but not actively used, and in stage 3 the work of folklore has disappeared in oral use, cf. E. Laugaste, Lectures in Estonian Folklore, p. 54.

12. E.g. ES, MT 289. 70/3 < Assikvere v. - A. Univere < Villem Bunder, 58 yrs. (1940); RKM 11 107. 446/50 (4) < Ranna - S. Lätt < Leida Laasma (1961); RKM II 102, 189/94 (3) < Raatvere v. - L. Reinsalu (1962).

13. Cf. ERA II 220, 193 (12) < Järva-Madise, Vetepere v. - S. Roopalu (1939), ERAII 225,612 (18) < Rapla. Pilpa v. - M. Sildam (1939).

14. While drawing a distinction, Laugaste emphasises above all attitudes: the aim of a joke or an anecdote is to show negative characters in a comical light, while a personal historical narrative emphasises the character's positive qualities (Laugaste 1957: 71). 


\section{Sources:}

FKRK - Folklore Archives of the Chair of Estonian Literature and Folklore, University of Tartu.

ERA - Estonian Folklore Archives; a folklore archives under the same name at the Department of Folklore of KAA

ES, MT - Dialectal Archives of the Estonian Language Society, Estonian Academy of Sciences.

KKI - Estonian Institute of Language and Literature, Estonian Academy of Sciences; a folklore archives in the folklore department of the Institute.

KM KO - Manuscript files of the Estonian Literary Museum, Estonian Academy of Sciences.

KM RO - Department of Folklore, Estonian Literary Museum, Estonian Academy of Sciences.

m - file

\section{References}

Anderson, Walter 1923. Kaiser und Abt. Die Geschichte eines Schwanks. FF Communications, 42. Helsinki: Suomen Tiedeakatemia.

Ferenczi, I. 1966. Törtenelem, szajhagyomany, mondahagyomany. Ethnographia LXXVII, No. 1. Budapest.

Hiiemäe, Mall 2001. Geschichten von Waldtieren als Tatsachenberichte. Folklore als Tatsachenbericht. Beyer, Jürgen \& Hiiemäe, Reet (ed.) Tartu: Sektion für Folkloristik des Estnischen Literaturmuseums, pp. 37-53.

Kolk, Udo 1959. Rahvalauluvariandi mõistest [On the Concept of Folk Song Variant]. Keel ja Kirjandus No. 2.

Krikmann, Arvo 1965. Küsimusi rahvanaljandite alalt 1 [Questions about Folk Humour]. Rahvapärimuste koguja 4. Tartu: Fr. R. Kreutzwaldi nim. Kirjandusmuuseum.

Laugaste, Eduard \& Normann, Erna 1965. Muistendid Kalevipojast. Hiiu- ja vägilasmuistendid I [Legends of Kalevipoeg. Giant and Hero Legends I]. Monumenta Estoniae antiquae 2. Tallinn: Eesti Raamat.

Laugaste, Eduard 1946. Eesti rahvalaulude uurimise metodoloogilisi lähtekohti [The Methodological Bases for Studying Estonian Folk Songs]. Looming, No. 4.

Laugaste, Eduard 1957. Kalevipoja-muistendite tüpologiseerimisc küsimusi [Problems of Typology with Legends of Kalevipoeg]. "Kalevipoja" küsimusi. TRÜ Toimetised, vk 52. Tartu: TRÜ Kirjastus.

Leach, Maria (ed.) 1950. Funk \& Wagnalls Standard Dictionary of Folklore, Mythology and Legend II. New York: HarperCollins Publisher, pp. 1137-1138. 
Loorits, Oskar 1940. Ununevast kultuurimiljööst: mit einem Referat : Aus verschollenem Kulturmilieu. Eesti Teaduste Akadeemia aastaraamat I. Tartu: K. Mattiesen.

Lätt, Selma 1962. Kodavere humoristlikud jutud [The Humorous Tales from Kodavere]. Ettekanne vabariiklikul rahvaluule-alasel konverentsil. Tartu 1962. Käsikiri KM RO-s.

Moora, Aliise 1964. Peipsimaa etnilisest ajaloost: ajaloolis-etnograafiline uurimus Eesti-Vene suhetest [On the Ethnic History of Peipsi Region: a historico-ethnographical study on Estonian-Russian relations]. Tallinn: Eesti Riiklik Kirjastus.

Neumann, S. 1966. Arbeitserinnerungen als Erzählinhalt. Deutsches Jahrbuch für Volkskunde. 12: II. Berlin, pp. 177-190.

Pino, Vera 1964. Laulurühma «Kubjas ja teomees" tüpoloogilistest suhetest [On the Typological Relations of Song Group "Superintendant and worker"]. Eesti rahvaluulest. Tallinn: ENSV Teaduste Akadeemia, pp. 35-51.

Proodel, Mall 1967. Loomajutud tänapäeval [Animal Tales Today]. Keel ja Kirjandus, No. 3, pp. 281-285.

Põldmäe, Rudolf 1941. Eesti rahvanaljandid I [Estonian Folk Humour I]. Inimese eluperioodid Tartu: Teaduslik Kirjandus. See also http:// www.folklore.ee/rl/pubte/ee/nali/

Raudsep, Loreida 1969. Antiklerikale estnische: Schwänke. Typen- und Variantenverzeichnis. Tallinn: Institut für Sprache und Literatur der Akademie der Wissenschaften der Estnischen SSR.

Rüütel, Ingrid 1969. Rahvalaulu-terminoloogia probleeme [Terminology Problems with Folk Songs]. Keel ja Kirjandus 1969: 2.

Simonsuuri, Lauri 1951. Kotiseudun tarinoita [Local Legends]. Helsinki: Suomalaisen Kirjallisuuden Seura.

Sirovatka, O. 1961. Der gegenwärtige Stand der tschechischen Volkserzählung. Ranke, Kurt (ed.) Internationaler Kongress der Volkserzählungsforscher in Kiel und Kopenhagcn (19.8.-29.8.1959). Vorträge und Referats. Berlin: De Gruyter.

Sõgel, Endel (ed.) 1965. Eesti kirjanduse ajalugu: viies köites [History of Estonian Literature: in five volumes]. 1. Esimestest algetest XIX sajandi 40-ndate aastateni I. Tallinn: Eesti Raamat.

Sydow, C. W. 19 Kategorien der Prosa-Volksdichtung. Selected Papers on Folklore. Copenhagen: RosenKilde and Bagger.

Tedre, Ülo 1964. Tähelepanekuid regivärsilise rahvalaulu tüpoloogiast [Notes on the Typology of Runic Folk Songs]. Eesti rahvaluulest. Tallinn: ENSV Teaduste Akadeemia.

Tedre, Ülo. Rahvaluule proosaliigid [Prose Types of Folklore]. Sõgel, Endel (ed.) 1965. Eesti kirjanduse ajalugu: viies köites. 1. Esimestest algetest XIX sajandi 40-ndate aastateni I. Tallinn: Eesti Raamat. 